\title{
The use of business information by small and medium-sized enterprises in Acornhoek
}

\author{
J K Shokane \\ University of the North Library, Private Bag XI I I2, Sovenga 0727, South Africa \\ shokanej@unorth.ac.za
}

\begin{abstract}
Received: $28^{\text {th }}$ May 2002
Revised : $16^{\text {th }}$ August 2002

In the modern global economy, business information presents a potential for contributing to the success and wealth of the economy and, thereby, serving as a source of gaining sustainable competitive advantage for modern business enterprises. Small and medium-sized enterprises are making a fundamental impact to the contribution of the economy of South Africa. South African enterprises in metropolitan areas operate in a global market and must withstand the competitive pressures from other producers and from new alternative technologies and products. Business managers therefore need an input of competitive information and must manage and utilize this information. This article determines the extent to which small and medium-sized enterprises in Acornhoek make use of business information for sustainable competitive advantage.
\end{abstract}

\section{Introduction}

The aim of this study was to determine the extent to which small and medium -sized enterprises in Acornhoek make use of business information for sustainable competitive advantage. With the emergence of customer-driven enterprises, business information has progressively been considered to be an invaluable resource that accelerates the continued survival of the business environment as it performs a vital role in present day management (Wigand, Picot and Reichwald; 1997). Du Toit (1998) argues that information allows the enterprise to be more active within the internal and external environments, and can_be considered as a critical resource that creates competitive advantage. Business enterprises in today's complex organizational world are experiencing rapid changes in an increasingly competitive setting.

With the dire need to respond recurrently to changing market conditions, coupled with the reshaping of basic business structures, require that competitive enterprises must either use information to improve products, services and internal processes or create new markets (Wigand, et al, 1997). Business managers should have access to a wide range of factual competitive information on the one hand, and be conversant with the dynamics to explore these information sources on the other hand.

Despite the fact that information has increasingly been considered as an important resource alongside other traditional resources to be utilized by modern business enterprises, there is still apparent lack and need for information by business enterprises in the rural areas of South Africa. The apparent lack of interest in business information could be attributed to two things. Terblanche and Du Toit (1996) argue that on the one hand, business managers lack systematic information skills. Hence they often lack the confidence to ask for appropriate information. Frequently, they also do not know how to manage the available information. On the other hand, information specialists have insufficient knowledge or no knowledge of the true information needs of some potential users, namely business managers (Terblanche and Du Toit, 1996). Business managers within business enterprises often have access to sources of comprehensive business data.

However, whilst decision-makers are consequently often faced with excess data, an element of paucity of information for competitive advantage cannot be ruled out. Tricker (1982:I) shares this when he succinctly states that "providing of more data, more accurately, more quickly and making it more readily accessible does not, of itself provide more information, even less does it produce better informed executives."

With the recurrent changes taking place as a result of globalization coupled with the perpetual use of information technology, the researcher asserts that the time has come for business enterprises, particularly in the rural areas of South Africa, to integrate information resources more effectively with other enterprise functions. In this manner information could become a strategic tool for reaching a competitive advantage (Du Toit, 1995).

This assertion is advanced against a background in which systematic guidelines for managers hardly exist about how to obtain information. The other underlying factor could be that today's modern business enterprises, particularly in metropolitan areas, are faced with growing complexities, one of which is information explosion. These factors have serious implications for business management in general.

Seen against the exposition provided above, this article aims to determine the extent to which small and mediumsized enterprises in the rural area of Acornhoek make use of business information for sustainable competitive advantage. Based on the aim of this article, the following objectives can be formulated for this article:

- To determine the information needs of small and medium-sized enterprises business managers

- To indicate the various information sources for small and medium-sized enterprises 


\section{Business managers' information needs}

The business environment is changing recurrently particularly for small business enterprises in South Africa. As a result this has a result given rise to both risks and opportunities for these enterprises. Mchombu (2000) postulates that this could be attributed to the tough competition as more business enterprises use highly sophisticated technology to harness competitive information. Although business information is generated in a variety of formats, ranging from an informal to a formal channel of communication, Pineda and Lerner (1998) argue that the sources of managerial information can be classified to those, which are internal or external, and whether these sources are personal or impersonal. Dalton (1989) however contends that managers in business enterprises use the following sources of information:

- Personal contact, for example, established entrepreneurs and friends;

- Newspapers;

- Printed sources, for example trade literature, journals and reports;

- Solicitors;

- Mass media such as television and radio;

- Advisory services;

- Information centers; and

- Sources available on the Internet, etc.

In spite of the importance of the various sources indicated above, Butcher (1997) indicates that to solve problems, business managers very reasonably turn to someone else (subordinates, peer contact etc) to discuss information in an attempt to form some consensus about the usefulness thereof. He further expounds that oral communication has many advantages: feedback is instantaneous, misconceptions can be corrected, point's clarified and additional information can be provided. This personal discourse is a primary source of information for managers. Managers believe that information obtained in this way can be relied upon because they have a special relationship with the sender. It is clear that business managers should be able to tap verbal sources, which may be of use to them. As a result, regular meetings with subordinates can afford business managers an opportunity to collect trigger information. The trigger information is about potential business and entrepreneurial opportunities, which trigger operational, control and strategic activities that are performed in enterprises. This trigger information frequently takes the form of hearsay and gossip. Managers show a marked preference for this type of information, believing that "yesterday's rumour is today's business opportunity" (Butcher, 1997:2). According to Auster and Choo (1993) business managers prefer newspapers as a source of information. They point out that a newspaper offers the opportunity not only to address specific problems but also to get a wide view of the business environment and search for information, which might trigger a business opportunity.

Choo (1995) stresses that the identification of information needs should be rich and complete in representing and elaborating user needs. According to Taylor (1986) information needs consist of two categories, namely, those pertaining to the subject matter, i.e., what information is needed, and those arising from the situational requirement of utilizing this information.

According to Butcher (1998) small business managers seem unable to explain their needs. Several reasons could be attributed for this. they are unaware of what information is available, and also do not understand how such information can be used. They are also unaware of the information delivery methods options. Consequently, those charged with the provision of information within business enterprises such as builders of information systems, often design systems based on their assumptions about the kinds of information which the small business managers of the business enterprises in question will require; they make expensive decisions about information provision based on discussions with relevant business managers.

Against the background information provided above, Butcher (1997) indicates that a number of user surveys conducted by authors on the subjects of usage of information, show that the business enterprises' need for information will inevitably increase in the future. Butcher (1997) contends that business managers execute three managerial roles in business enterprises, namely Firstly, operational tasks; these are the most basic tasks such as production and sales. Secondly, control tasks- such tasks ensures that resources are effectively and efficiently utilized in the accomplishment of the enterprise goals. Lastly, strategic goals- such tasks involve planning for the future.

Having identified the tasks, it is significant to ascertain what type of information is required in order to execute the above mentioned tasks. According to Kargbo (1997) there are two types of information needed in business enterprises, namely; current and everyday information. Ntsala (2000) argues that business enterprise information needs can be identified at two levels, Firstly, immediate information needs- this type of information is required to answer an immediate concern. This is likely to occur in crisis situation in which time and costs are of outmost concern. However, the rapid demand for information to be satisfied will depend appreciably on the reliability of the personal contact network. Secondly, prospective information needs- this type of information is basically treated as a long-term strategic resource. 
Pistorius (1989) stresses that businessmen require ongoing information on the external environment, i.e., the political, judicial, social, geographic, ecological, demographic, economic, financial and technological environments as well as technological and management information for decision purposes. Business managers frequently need this kind of information more speedily than academics and researchers to facilitate decision-making that could be profit-related. According to Olanigan (1987), the type of information needed by small business managers vary considerably. They range from general reference to more detailed relating to methods of production.

\section{Methodology}

This study was conducted using a survey method. A survey method is a method of collecting data from people about their feeling, beliefs, opinions and attitudes through the questionnaire and interview. Fink (1995) reiterates that the survey research is characterized by the selection of samples from a population to obtain empirical knowledge of a contemporary nature which allows generalization to be made about the characteristics, opinions, beliefs and attitudes of the entire population being studied. Due to the scarcity of research relating to use of business information by small and mediumsized enterprises in rural areas of South Africa, it was therefore decided to compile a semi-structured questionnaire to be completed by business managers in Acornhoek. The semi-structured questionnaire was an effort to determine the information needs of small and medium-sized enterprises in various business sectors, also to investigate where the business managers obtain their information. According to Leedy (1997:191) " a questionnaire is one of the best tools to probe data beyond the physical reach of an observer". The advantages for using pre-structured questionnaire for this article was that the questionnaire was personally distributed to selected small and medium-sized enterprises simultaneously and the responses were received within a month. Although the questionnaire was physically distributed, there was no available list of small and medium-sized enterprises in Acornhoek.

As it was impossible to identify a list of all registered small and medium sized enterprises registered with Local Business Service Centre in Acornhoek, a questionnaire using non- probable sampling called purposive sampling were distributed and self-administered to small and medium-sized enterprises in Acornhoek. Bailey (1997) states that with purposive sampling the researcher uses his or her own judgement on which participant to use and picks only those who best meet the purpose of this study. In general, a non-probability sample is appropriate whenever does not generalize beyond a specific sample of respondents. In this study, the small and medium-sized enterprises that operate their businesses in a business centre of Acornhoek were chosen. Enterprises that operate outside the vicinity of the Acornhoek business center were excluded from this study.

Given the fact that Acornhoek is small area, with approximately one million and two hundred thousand people and few business enterprises, a total number of thirty-five questionnaires were distributed and self administered to small and medium-sized enterprises in Acornhoek. Thirty-two questionnaires, which represent a $91 \%$ response rate, were returned. Despite the fact that the return rate was fairly high and the confidentiality of the questionnaires was assured, 3 (9\%) respondents refused to fill the questionnaire for fear that their business information might be used by other competitors. They also indicated that it was against their business policy to make such information available to researchers.

\section{Results}

The results are analyzed by personal details of the respondents, type of business, methods of communication to obtain information and frequency of the use of information.

Age of the respondents

The mean age of the respondents' is 40 years old with the youngest being 28 years and the oldest being 59 years old. This shows that the majority of the respondents are still young. The activeness of the young generation in business enterprises could be attributed to a variety of reasons such as unemployment, not wanting to work for somebody, assisting parents' etc. The business need arose as a result of the open economic policy of the new dispensation could also be ascribed as the reason why the majority of the respondents are still young.

\section{Gender}

Out of 32 respondents, $22(68.7 \%)$ are male business managers and $10(31.3 \%)$ are female business managers. It is interesting to note that female business managers are beginning to make a mark in managing small business enterprises particularly in rural areas. A variety of reasons, for example, gender equality in management of business enterprises, business courses offered to empower women, supplementing their husbands meagre income could be attributed to the fact why women begin to make a mark in becoming small and medium-sized business managers. The other reason could be that financial resources in the form of awards is being made available by leading enterprises such as Checkers and Sowetan, to successful female entrepreneurs who have established prosperous small business enterprises. 
Level of education

Out of 32 respondents, 13(40.6\%) have secondary education, whilst on the other hand $13(40.6 \%)$ have tertiary education. It is clear that the respondents have more than basic literacy education. Hence the data on educational attainment show that the respondents' level of education is not too low, thus placing them in good stead to comprehend business issues and concerns with ease. This means that the respondents have more than basic literacy that provides a potential for growth and improved management of their business, through the use of business information. The availability of both Mapulaneng Technical and Training colleges and other private colleges could be seen as another reason why majority of the respondents indicated that their level of education is good.

Type of business

Table I: The type of business composition $(\mathrm{N}=32)$

\begin{tabular}{lcc}
\hline Type of business enterprise & Frequency & $\%$ \\
\hline Retail & 5 & $15.6 \%$ \\
Service & 10 & $31.3 \%$ \\
Franchise & 5 & $15.6 \%$ \\
Manufacturing & 3 & $9.4 \%$ \\
Sales & 8 & $25 \%$ \\
Other(s) & 1 & $3.1 \%$ \\
\hline Total & $\mathbf{3 2}$ & $\mathbf{1 0 0} \%$ \\
\hline
\end{tabular}

With regard to the different types of business enterprises, 10 (31.3\%) respondents indicated that they are involved in service business, while $8(25 \%)$ respondents indicated that they are involved in sales business. The dominance of both service and sales business could in Acornhoek be attributed to the fact that these types of business enterprises are easily established, and have proven to yield profit quickly. Most small business managers venture in these types of businesses because they do not have enough money to start other types of businesses like a sales business which will "force" them to have money to buy initial stock. They have little money available to buy products to sell.

Methods of communication to obtain information

Table 2. The methods of communication to obtain information $(\mathbf{N}=32)$

\begin{tabular}{llll}
\hline Methods of communication & $\begin{array}{l}\text { Very } \\
\text { important }\end{array}$ & $\begin{array}{l}\text { Somewhat } \\
\text { important }\end{array}$ & $\begin{array}{l}\text { Not } \\
\text { important }\end{array}$ \\
\hline Discussions with colleagues & $25(78.1 \%)$ & $3(9.4 \%)$ & $4(12.5 \%)$ \\
Asking the librarian & - & $1(3.1 \%)$ & $31(96.9 \%)$ \\
Telephone conversation & - & $15(46.9 \%)$ & $3(9.4 \%)$ \\
Conferences & $13(40.6 \%)$ & $5(15.6 \%)$ & $25(78.1 \%)$ \\
Computerised information & $2(6.3 \%)$ & $9(28.1 \%)$ & $14(43.7 \%)$ \\
Discussion with people & $7(21.8 \%)$ & $9(28.1 \%)$ & $3(9.4 \%)$ \\
Discussion with subordinates & $19(59.3 \%)$ & $6(18.8 \%)$ & $6(18.8 \%)$ \\
Email & $20(62.5 \%)$ & - & $26(81.2 \%)$ \\
Others & $6(18.8 \%)$ & $1(3.1 \%)$ & $3(9.4 \%)$ \\
\hline
\end{tabular}

From the results revealed in Table 2, it is evident that the majority of small- and medium-sized enterprises prefer informal methods of communication to obtain information for their enterprises. Discussions with colleagues were seen to be very important methods of obtaining information. 25 (78.1\%) respondents indicated that they consider the informal manner of obtaining information to be useful. It is clear that small and medium-sized business enterprise managers in Acornhoek tend to rely on personal contact to collect information for their enterprise. Information obtained in this way has a special relationship with the sender.

Deliberations with subordinates were viewed to be very important as compared to deliberations with people outside the enterprise. $19(59.3 \%)$ respondents indicated that discussion with subordinates is considered to be a very important mechanism of collecting information for their business enterprise.

It appears from the respondents $13(40.6 \%)$ that telephonic conversation is a very useful means of obtaining information, as many small and medium-sized enterprise managers are usually conversant with this technique of sending and receiving information. It is lamentable to reveal that most respondents $30(96.1 \%)$ do not consider asking the librarian to be very useful in collecting information for sustainable competitive advantage. This could be attributed to the fact they there are no libraries or information centers that provide information and advance small- and medium-sized enterprises in Acornhoek. The only library that exists adjacent to these enterprises is approximately 44km in Hoedspruit. 
Of equal importance to note is that these businesses enterprises do not consider attending conferences to be useful. 25 $(78.1 \%)$ respondents indicated that they do not attend conferences that discuss business-related issues.

Although some respondents $20(62.5 \%)$ indicated that e-mail is very important for them to gather information for competitive advantage, the majority of the respondents, $26(81.2 \%)$, intimated that they do not view e-mail to be a very useful means of obtaining information. This implies that technology, particularly the Internet, is still unfamiliar, to smalland medium-sized enterprises that operate their business in the rural area of Acornhoek. An average of I 5 respondents who represent $46.9 \%$ indicated that computerized information services are important. This is in sharp contrast to 3 (9.4\%) who do not consider computerized information services to be important.

\section{Frequency of the use of information source}

Table 3. The frequency of the use of information source $(\mathrm{N}=32)$

\begin{tabular}{|c|c|c|c|c|c|}
\hline Information source & $\begin{array}{l}\text { To a very } \\
\text { large extent }\end{array}$ & $\begin{array}{l}\text { To a large } \\
\text { extent }\end{array}$ & $\begin{array}{l}\text { To some } \\
\text { extent }\end{array}$ & $\begin{array}{l}\text { To no } \\
\text { extent }\end{array}$ & Not applicable \\
\hline Friends, relatives, associates & $20(62.5 \%)$ & $5(15.6 \%)$ & $4(12.5 \%)$ & - & $3(9.4 \%)$ \\
\hline Local authorities & $\mathrm{I}(3.1 \%)$ & $3(9.4 \%)$ & $20(62.5 \%)$ & $5(\mid 5.6 \%)$ & $2(6.3 \%)$ \\
\hline Customers & $26(81.2 \%)$ & $3(9.4 \%)$ & $\mathrm{I}(3.1 \%)$ & - & I (3.1\%) \\
\hline Suppliers & $21(65.6 \%)$ & $7(21.8 \%)$ & $\mathrm{I}(3.1 \%)$ & - & $2(6.3 \%)$ \\
\hline Solicitors & $3(9.4 \%)$ & $2(6.3 \%)$ & $10(31.3 \%)$ & $4(12.5 \%)$ & $8(25 \%)$ \\
\hline Radio, television & $7(21.8 \%)$ & $\mathrm{II}(34.3 \%)$ & $8(25 \%)$ & $2(6.3 \%)$ & $3(9.4 \%)$ \\
\hline \multicolumn{6}{|l|}{ Small business information } \\
\hline centers & I (3.1\%) & I (3.1\%) & $5(15.6 \%)$ & $6(18.8 \%)$ & $19(59.3 \%)$ \\
\hline Commercial banks e.g. banks & I (3.|\%) & $2(6.3 \%)$ & $2(6.3 \%)$ & $6(18.8 \%)$ & $18(56.2 \%)$ \\
\hline Newspapers & $9(28.1 \%)$ & $3(9.4 \%)$ & $10(31.3 \%)$ & $3(9.4 \%)$ & $6(18.8 \%)$ \\
\hline Magazine & $9(28.1 \%)$ & $3(9.4 \%)$ & $\mathrm{II}(34.3 \%)$ & $4(12.5 \%)$ & $5(15.6 \%)$ \\
\hline Business councils & $9(28.1 \%)$ & $3(9.4 \%)$ & $4(12.5 \%)$ & $2(6.3 \%)$ & $12(37.5 \%)$ \\
\hline Libraries & - & $\mathrm{I}(3.1 \%)$ & $2(6.3 \%)$ & $3(9.4 \%)$ & $24(75 \%)$ \\
\hline Trade associations & I $(3.1 \%)$ & I $(3.1 \%)$ & I (3.1\%) & $7(21.8 \%)$ & $21(65.6 \%)$ \\
\hline Research institute & $\mathrm{I}(3.1 \%)$ & - & $2(6.3 \%)$ & $4(12.5 \%)$ & $24(75 \%)$ \\
\hline The Interrnet & $3(9.4 \%)$ & $2(6.3 \%)$ & - & $4(12.5 \%)$ & $23(71.8 \%)$ \\
\hline Professional journals & $2(6.3 \%)$ & - & $4(12.5 \%)$ & $3(9.4 \%)$ & $22(68.7 \%)$ \\
\hline Textbooks & - & $3(9.4 \%)$ & $8(25 \%)$ & $5(15.6 \%)$ & $16(50 \%)$ \\
\hline Handbooks & - & $3(9.4 \%)$ & $7(21.8 \%)$ & $6(18.8 \%)$ & $16(50 \%)$ \\
\hline Patents, standards & - & I (3.1\%) & $1(3.1 \%)$ & $5(15.6 \%)$ & $24(75 \%)$ \\
\hline Report of other enterprises & I (3.1\%) & $4(12.5 \%)$ & $7(21.8 \%)$ & $2(6.3 \%)$ & $16(50 \%)$ \\
\hline Trade report & - & $7(21.8 \%)$ & $6(18.8 \%)$ & $3(9.4 \%)$ & $16(50 \%)$ \\
\hline Others & - & - & - & $2(6.3 \%)$ & $4(12.5 \%)$ \\
\hline
\end{tabular}

From this Tabłe, it is evident that informal sources are used to a very large extent. 20 (62.5\%) respondents' say that they use friends, relatives and associates to a very large extent, while $26(81.2 \%)$ indicated that they used customers. This may be due to their frequent interaction and constant contact with the customers. II (34.3\%) indicated that they use radio and television to a large extent. This could be attributed to the fact that these sources of information are easily accessible.

$20(62.5 \%)$ respondents indicated that they, to some extent, make use of local authorities to support their enterprise activities. When these results are compared to data in Table 2, it appears that there is a similarity in the frequency of the usage of local authorities. From the Table, it is also lamentable in the vicinity of Acornhoek area to realize that libraries are less used by small- and medium-sized enterprises. 24 (75\%) respondents indicated that they do not make use of libraries at all. This could arise from many factors. However, at the moment lack of libraries at the vicinity of the enterprises is a major contributing factor.

Despite the fact that the Internet is used by many enterprises for various reasons such as marketing products, it was not the case to small- and medium-sized enterprises operating in Acornhoek. 23 (71.8\%) indicated that the Internet is not available in their business enterprises. The non-availability of Internet in most enterprises could be attributed to the fact that Internet is still unfamiliar to them. It is also clear from the Table above that half of the respondents 16, (50\%) still do not regard technical or trade publications to have an effect on the management of their enterprise activities.

\section{Discussions}

Small and medium-sized enterprises operating in rural areas of South Africa are confronted by many problems, which often vary according to the specific type of enterprise. This study, however, does not claim to have identified problems facing small and medium-sized enterprises in tapping competitive information in other rural areas of South Africa. It is, rather, aimed at gaining understanding of the information needs of small and medium-sized enterprises in Acornhoek and 
the extent to which they make use of business information to gain sustainable competitive advantage. From the findings of this study, it was clear that many small and medium-sized enterprises managers' level of education was good. There is however, still persistent ignorance in accessing business information for managing their enterprises. Mashego (2002) concurs that the paucity of accessibility to information by this sector could be lack of entrepreneurial behaviour and illiteracy. The researcher contends that this could also be applicable to other small and medium-sized enterprises in other rural areas of South Africa. Inspite of the fact that many small and medium-sized enterprises in Acornhoek are owned by literate business managers, Erwin ( 2000 and 200I) and Shokane (200I) argue that there is still prevalence of unclear competitive strategies, lack of knowledge regarding their information needs and uptodate information sources, wariness in installation of technological devices and poor financial control, among small and medium-sized enterprises in rural areas.

With regard to the type of business enterprise that they owned, it is apparent from this study that both service and sales businesses are dominating in Acornhoek. Ntsala (2000) found that many small and medium sized enterprises lack entrepreneurial spirit, appropriate education, training and development initiatives that focus on small and medium-sized enterprises, hence majority of the enterprises were involved in one category of business enterprise. It should be realized that involvement in one category of business has some drawbacks, for example, when enterprises sell the same products their business do not flourish, or attract desired benefits in the form of profit or growth as a result of fierce and antagonistic competition from other business selling the same products. Moreover, the redundancy of same products cripples their businesses (Ntsala, 2000)

It becomes apparent from this study that most of the small and medium-sized enterprises in Acornhoek still depend on informal sources to obtain information to manage their business activities. These results support earlier findings by Auster and Choo (1993), Terblanche and Du Toit (1996), Pineda and Lerner (1998) who concur that informal sources are the most preferred sources of information for many business enterprises to formal sources. Pineda (1998) argues that business enterprises tend to rely on informal sources such as family and friends, while Butcher (1997) notes that business enterprises obtain information through verbal exchanges with the suppliers, customers, distributors. Butcher (1998) argues in favour of dependence on informal sources of information by identifying its advantages as follows: feedback is instantaneous, misconception can be corrected, point's clarified and additional information can be provided. This is particularly true for small and medium sized enterprises in Acornhoek who tend to rely on informal sources to obtain information and make multiple decisions in a wide range of areas. Additionally, they may not know other methods for obtaining information. Although they appear to rely on informal sources of information, it is likely that their gathering of information varies with the issue or decision under consideration

Although some studies have concluded that some small enterprises do engage in extensive environmental scanning, it was revealed from this study that such scanning is still unknown to many small and medium-sized enterprises in the rural areas. Inspite of the fact that small and medium-sized enterprises do not conduct environmental scanning to obtain information due to resource constraints, Choo (1993) recommends that environmental scanning enables business enterprises in the task of charting their enterprise future course of action. He further argues that business managers who perceive greater uncertainty tend to scan the environment more. It therefore remains a constant challenge for these enterprises to conduct environmental scanning for their continued survival. This would enable them not to establish their business hapharzadly without considering what services and goods are offered by other business enterprises

The development of computerized information systems has contributed to the fact that information is arranged, analyzed and presented in such a way that it assists business managers in their decision making, planning and control of the enterprises. With regard to the use of computerized information services, this study revealed that there is absolute lack of familiarity with the changing technology especially the Internet among small and medium-sized enterprises in Acornhoek. This could be attributed to the remoteness of the areas. Kargbo (1997) shares this view by arguing that many enterprises especially in rural areas are confronted with profound problems such as lack of strategic capacities, sufficient and sustainable structures needed to get connected to the Internet. It should be noted that the failure of these enterprises to exploit computerized information services would inevitably incapacitate them to clearly articulate the information needs and address them deliberately.

The degree to which small and medium-sized enterprises frequently use radio and television to a large extent could be associated with their information search activities. It is then fair to say that for those enterprises that tend to rely on radio and television, there is a superior chance to get as much information as possible. It also emerged from this study that local authorities were to some extent used by small and medium-sized enterprises. The main reason for using local authorities is that they play a central role in demarcating business sites. The shortage of libraries and information centers as sources of information in rural areas has far reaching implications for the management of business enterprises, hence they are not used at all by majority of business enterprises. Patents and trade are not frequently used. The researcher firmly contends that these business enterprises could not be aware of these sources. This viewpoint, however, contrasts with Terblanche 
and Du Toit (1996) in their study conducted in Bloemfontein, which is a metropolitan area, which revealed that the majority of respondents persistently make use of these sources of information.

\section{Conclusion}

It appears that owing to the inaccessibility of information to small and medium-sized enterprises in rural areas due to lack of technological resources such as Internet to facilitate accessibility and information sharing, business managers do not regard information as a resource that can help them to attain sustainable competitive advantage. This is evident because many small and medium-sized enterprises still do not know where to obtain their sources of information. This observation contrasts with Terblache and Du Toit (1996) study in which they report that information is essential for the continued existence and prosperity of enterprises, as well as for the economic wealth of the country. Based on the conclusion derived from this study, it is recommended that with the increasing use of Internet, particularly the World Wide Web by modern business enterprises, small and medium-sized business enterprises should consider investing in Web technology to enhance their business activities and increase productivity. This study found that many small business managers lack information on managing their businesses, and that many are not aware of their information needs and how business information services can support and advance their business activities. It is recommended that a business information service supporting small and medium sized enterprises be started. This business information service should have a wide range of information sources and services developed on the basis of thorough and adequate knowledge of small business information seeking behavior.

\section{References}

Auster, E. and Choo, C.W. (1993). Environmental scanning: acquisition and use of Information by managers. Annual Review of Information and Technology, 28: 279-3I4.

Bailey, K.D. (1997). Methods of social research. London: Free press

Butcher, H. (1997). Why don't managers use information. Infotoday. Retrieved 4 March 1998, from http://www.aslib.co.uk/maninfmay97.article.html

Butcher, H. (1998). Meeting managers' information needs. London: Aslib. Retrieved 04 April 2000, from http://www.aslib.co.uk/ pubs. 2000/05/04/html

Choo, C. W. (1993). Environmental scanning: acquisitions and use of information by managers. Annual Review of Information Science and Technology, 28: 279-3I4.

Choo, C. W. (1995). Information management for the intelligent organization: Environmental

scanning as strategic learning organizations, Retrieved 9September 1999, from http://choo.fis/utoronto/ca/fis.IMIO.IMIO4.html

Dalton, G. (1989). The small business owner and the role of the public library. Mousaion, 7 (I): 24-39.

Du Toit A. S. A. (1995). Managing intelligence: a new paradigm for South Africa. Management dynamics, 4 (3): 17-36.

Du Toit, A. S. A. (1998). Information management in South African manufacturing enterprises. International journal of information management, 18 (3): 205-213.

Erwin, A. (200I). Government thinks BIG on small enterprises. Business Times, 17 February $200 \mathrm{I}$.

Fink, A. (1995). The survey handbook. London: Sage

Kargbo, J. A. (1997). Business information and the Internet in the developing world. (Online) Available WWW. http:// www. firstmonday/issues29/kargbo/index.html

Leedy, P.D. (1997). Practical research: planning and design. $6^{\text {th }}$ ed. Merrill. New Jersey

Mashego, M. (2002). Banks accused of stunting small business. City Press. 26 May 2002

Mchombu, C.M. (2000). Information needs of women in small businesses. The international information and library review, 32 (I): 39-67.

Ntsala, M. J. (2000). Information delivery systems for small businesses. In. I. Wormell (ed), ProLLISA. Progress in Library and Information Science in Southern Africa. First Biannual DiSSanet Conference, 27-28 October: University of Pretoria: $167-176$

Olanigan, S. A. (1987). Information needs of the consultant to small businesses enterprises. International Library Review, 19 (4): 345-358.

Pineda. $L$ and Lerner, L.D. (1998). An investigation of factors affecting the information - search activities of small business managers. Journal of small business management, 36 (I): 60-7I.

Pistorius, J.M. (1989). Information transfer needs and problems for businessmen: a literature survey. South African Journal of Library and Information Science, 29 (1): 19-28.

Shokane, J.K. (200I). The use of business information by small and medium-sized enterprises in Acornhoek. M.Inf Dissertation. Johannesburg: Rand Afrikaans University (unpublished)

Taylor, R. S. (1986). Value added processes in information systems. Norwood: Ablex Publishing Company.

Terblanche, C. A. and Du Toit, A. S. A. (1996). Technikon information services to commerce and industry: an exploratory study. South African Journal of Library and Information Science, 64 (2): I0I- 107.

Wigand, R, Picot, A and Reichwald, R. (1997). Information, organizations and management: expanding and corporate boundaries. Newyork: John Wiley \& Sons.

Tricker, R. I. (1982). Effective information management: developing information systems strategies. Oxford: Beaumont Executive Press. 